of the remaining twelve. Then this series broke down, but from 1889 until 1909 there was a most remarkable sequence in which every third year was abnormally wet. 'The years 1891, 1894, $1897,1900,1903,1906$, and 1909 were all wetter than the average ; of the remaining eighteen, one was exactly normal and the others were all dry. After 1909, however, the sequence changed to an almost equally remarkable two-year oscillation. From 1910 until 1922 the even years were all much wetter than the average, while the odd years were all dry, with the sole exception of 1915 , and even that year was drier than either 1914 or 1916 . After 1922 this two-year sequence broke down, and now we seem to have returned temporarily to the three-year type.

\title{
Progress in Naval Engineering.
}

\section{By Eng. Capt. Edgar C. SMith, O.B.E., R.N.}

$\mathrm{T}$ HOUGH surpassed in length by the presidential address of Sir William White to the Institution of Civil Engineers in 1903, the Thomas Lowe Gray lecture delivered to the Institution of Mechanical Engineers on Jan. 3 by Engr. ViceAdmiral R. W. Skelton, Engineer-in-Chief of the Fleet, on progress in marine engineering, bears comparison with it as an authoritative official review of an important subject. While Sir William White traced the evolution of mercantile and naval vessels, Admiral Skelton confined himself to the progress in marine machinery, and his lecture is probably the most extensive survey so far written. His predecessors, Admirals Durston, Oram, Goodwin, and Dixon, in their addresses and papers to the technical institutions, have all dealt with various aspects of naval and marine engineering, and were the series of contributions collected in a single volume it would go far towards filling one of the many gaps in the literature of engineering history. Such a volume should at least be available in every man-of-war and every school where marine engineering is studied.

Though not mentioned by Admiral Skelton, the first suggestion for a steam-driven war vessel was made to the Admiralty by Earl Stanhope. For him the authorities built the 'ambinavigatorship', called the Kent, and so sure did Stanhope feel that he was on the high road to success that in June 1794 he signed a bond with a penalty of $\$ 9000$ " to indemnify the public in case the said ship should not answer the purpose of Government". The inventor did not merely intend to produce a result, but he hoped "to establish every part of the subject on clear and irrefragable proofs, and to ascertain demonstratively what is the best possible plan". The experiments failed and the matter was dropped, without Stanhope, however, being kept to his bond. Twenty years elapsed before the Navy had anything more to do with steam, and then the suggestion came from Sir Joseph Banks. Capt. Tuckey was preparing for surveying the river Congo in the Congo. Why not fit her with a steam engine? Constructed by the greatest engineering firm in the world, Boulton and Watt, the engine was delivered, put into the ship, taken out again and set up in Chatham dockyard. So heavy was the machinery that the Congo would have foundered in any sort of sea, and Capt. Tuckey therefore wisely decided to stick to sails. Five or six years passed and with the building of the Comet, Lightning, and other small steam craft began a series of revolutionary changes in everything pertaining to warships.

It cannot be said that early naval requirements made any severe call on the engine constructors of the day. Fulton had launched the Clermont in 1807, Bell the Comet in 1812, and steam vessels were proving their worth on every ocean. But few realised the value of steam in war vessels, and there was no more stubborn opponent of steam than Capt. Sir William Symonds, the Surveyor of the Navy. The Russian War of the 'fifties, however, showed the futility of any longer trusting exclusively to the wind, and on April 22, 1854, the officers and men of the Black Sea fleet saw for the last time a British frigate in action under sail. By that time, slow as progress had been, the paddle had given place to the screw, the flue boiler to the tubular boiler, engines were becoming more powerful, and many of the younger generation of naval officers, who knew more about railways and electric telegraphs than of the fighting of the Napoleonic wars, had eagerly taken up the study of engineering.

Admiral Skelton gave much interesting information regarding those early days, and then proceeded to review matters which are more familiar to our ears. He was unable to read the whole of the lecture, which, however, will be published in full by the Institution of Mechanical Engineers. When available it will be seen to contain as an appendix a tabulated statement of some forty ships, from the fine paddle frigate Terrible of 1842 to the cruiser Berwick of 1925. It is a happily chosen list, and the progress of naval engineering could well be traced by a study of a ship from each decade. The fourth ship in the list is the Agamemnon of 1851. Other wooden two-deckers had been altered to receive the screw, but the Agamemnon was the first of her class to be designed as a screw ship. Her engine by Penn would reflect credit on any shop to-day. It was a simple expansion horizontal engine with two cylinders fitted with trunk pistons something like the pistons found in a motor-car. The square tubular boilers generated steam at $20 \mathrm{lb}$. pressure, and the engine developed $2268 \mathrm{~h} . \mathrm{p}$. The machinery weighed $320 \mathrm{lb}$. per h.p., cost $£ 159 s$. per h.p., and consumed $5 \mathrm{lb}$. of coal per h.p. per hour. Compare this with the Berwick, the machinery of which, developing 80,000 h.p., weighs only $45.5 \mathrm{lb}$. per h.p., cost but $£ 5.6$ per h.p., and consumes only $0.89 \mathrm{lb}$. of oil per h.p. per hour.

Under the command of Capt. W. R. Mends the

No. 3143 , VoL. 125] 
Agamemnon was sent to the Mediterranean under sail ; took part in the bombardment of Sevastopol in October 1854, and the following month successfully rode out the great storm which worked havoc in the fleet. Mends, who had studied the steam engine, had an anxious time, but after the storm wrote to his wife: "I soon had a third anchor down and kept the engine going to ease the cables, which, thanks to James Watt, enabled the good ship Agamemnon to ride easily".

The twenty pounds pressure of the Agamemnon represented the general practice at sea, marine engineers being timid regarding the use, and ignorant of the value, of high pressure steam. A step forward was made in the Constance of 1860 , which had John Elder's compound engines working with $30 \mathrm{lb}$. pressure. No one would want to be shipmates with her engines to-day, for they were most difficult to handle and maintain. Elder, however, was the leading advocate of the compound engine, around which a tremendous controversy raged, but which by the 'seventies was specified for all naval vessels. The early twin-screw ironclad Dreadnought of 1872 , for example, had vertical compound engines of 8207 h.p. working at $60 \mathrm{lb}$. pressure, and her coal consumption was but $2 \cdot 32 \mathrm{lb}$. as against the $5 \mathrm{lb}$. of the Agamemnon of twenty years earlier. It was about this time that engineers began to understand something of the work of Joule and his contemporaries on the mechanical equivalent of heat. In the Royal School of Naval Architecture and Marine Engineering, too, naval engineers were trained under some of the finest teachers of the day, among whom was Prof. Unwin, who is happily still with us, a veteran of more than ninety years.

From the 'seventies onward change succeeded change. The compound engine of Elder gave way to the triple expansion engine of Kirk, square boilers were replaced by cylindrical boilers, steam invaded every part of the warship, and the chief engineer of an ironclad became the head of a staff upon whose efforts mainly depended the efficiency of the ship as a fighting machine. Nineteenth century mechanical engineering could show nothing finer than the great triple-expansion reciprocating engines such as were found in the Atlantic liners, and in such cruisers as the Drake and Good Hope, each set of the engines of which developed 15,000 h.p. They were constructed when the demands of the naval authorities for greater speeds were inces- sant and when the attempts to comply with those demands brought a whole host of difficulties. There were troubles with boilers, with condensers, with bearings, thrusts, pistons, pumps, auxiliaries, packings, pipes, joints, glands, and valves. Engine designers did their utmost to overcome the defects, but it was, as Admiral Skelton said, upon the engineering branch of the Navy that the brunt of the work fell. Yet it was also in the arduous times of the 'eighties and 'nineties that naval engineers gained the experience which proved of such vital importance to the Empire during the War.

Of the forty-four ships in the Table, fifteen are turbine driven. The list begins with the Amethyst and Dreadnought, and includes such well-known vessels as the Glasgow, Lion, Hood, and Nelson. No one is likely to disagree with the remark that the successful application of the steam turbine afloat was largely due to the soundness of the conceptions of the inventor and his thorough exploratory work in connexion with the marine application. Had all innovations into the engine rooms of warships been accompanied by as few setbacks as was the turbine, naval engineering recollections would be far less interesting than they are. The importance of the change from reciprocating engine to steam turbine is comparable with the importance of the change from paddle to screw ; and so far as can be seen at present the turbine appears likely to hold its own for warship propulsion for a long time.

The introduction of the water-tube boiler came before the turbine, but the change from coal burning to oil burning has taken place in the last twenty years, and improvements in the stokehold have been as great as those in the engine room. The results can be seen by comparing the Dreadnought of 1905, the Hood of 1916, and the Berwick of 1925 . The weight of machinery per horse-power, has diminished in the ratio $184: 84: 45 \cdot 5$, the square feet of floor space required per horse-power in the ratio $0 \cdot 45: 0 \cdot 136: 0 \cdot 118$, while the cost of the machinery per horse-power of the three ships was $£ 13 \cdot 9$, $£ 9 \cdot 6$, and $£ 5 \cdot 6$ respectively. There is necessarily an ultimate limit in the possible reduction in weight and size and fuel consumption, and some writers forty years ago thought they were within measurable distance of it, but the age of improvement is still with us and engineers are still striving, like Earl Stanhope, to determine " what is the best possible plan".

\section{Obituary.}

Major P. G. Craigie, C.B.

$\mathrm{M}$ AJOR PATRICK GEORGE CRAIGIE, the leading authority for some half a century on agricultural statistics, died on Jan. 10 at the age of eighty-six years. Educated at Perth, the University of Edinburgh, and St. Catharine's College, Cambridge, he acted as secretary to the Local Taxation Committee from 1871 until 1890 and of the Central Chamber of Agriculture from 1879 until 1890. He was twice employed by Royal Commissions to report on the markets of Paris and Brussels, and on the agricultural schools of France. Shortly thereafter, on the formation of the new Board of Agriculture, he was selected as the obvious man for the directorship of the Statistics, Intelligence, and Education Branch, a post which he held from 1890 until 1897, when he became Assistant Secretary, retiring in 1906. Craigie was the founder of modern British agricultural statistics, and their value is largely due to bis enthusiasm and initiative.

No. 3143 , VoL. 125] 